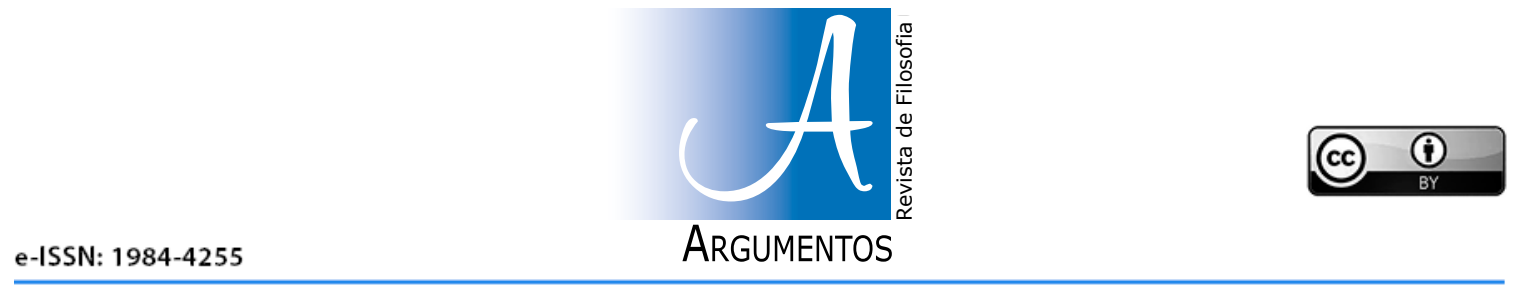

D0I: https://doi.org/10.36517/Argumentos.23.11

$\underline{\text { RESENHA }}$

\title{
Justiça em tempos sombrios de Christina Miranda Ribas
}

\author{
Odílio Alves Aguiar \\ https://orcid.org/0000-0002-7767-1932 - E-mail: odilio@ufc.br
}

Tendo por eixo o tema da ruptura totalitária, Justiça em tempos sombrios faz uma instigante reconstrução das principais preocupações de Arendt, com o intuito de investigar o que ela teria a dizer sobre a justiça, a partir de suas reflexões sobre as questões políticas fundamentais que aparecem em sua obra.

Nesse desiderato, a autora passeia com desenvoltura pelo pensamento de Hannah Arendt, costurando caminhos a partir de um ponto focal: o julgamento de Adolf Eichmamn, em Jerusalém, relatado por Arendt em obra polêmica, de grande repercussão. $O$ tema da justiça está, ali, subjacente, uma vez que, para Arendt, a realização da justiça é o propósito de um julgamento. Abordando os principais problemas jurídicos que o caso Eichmann apresentou, a obra apresenta a contraposição entre a percepção da justiça como uma virtude, própria da antiguidade, e a percepção da justiça como um valor, nascida com os modernos e vai encontrar seu apogeu na obra de Hans Kelsen. Para Christina Ribas, a ideia de que a justiça é um valor veio pouco a pouco a impregnar, de forma sub-reptícia, as diversas teorias contemporâneas da justiça. Como um valor entre outros, na imensa relatividade que caracteriza o contemporâneo, a justiça sofre uma espécie de perversão, perdendo seu significado e sua capacidade de iluminar o presente.

Isso fica evidente no julgamento de Eichmann, exatamente porque não haviam nem leis nem precedentes judiciais para o genocídio, brotando ali de forma contundente as perplexidades dos julgamentos do pós-guerra, relativos a crimes que se revestiam do manto da legalidade. Nesse sentido, como afirma Celso Lafer, assinando uma apresentação na forma de Orelha, um juízo determinante, baseado na subsunção, seria inadequado no contexto da ruptura totalitária: "Isto não só porque não havia norma positiva aplicável mas também porque não cabia nem a analogia juris de princípios gerais, pois estes eram inexistentes e fugidios, nem a analogia legis, pois esta pressupõe a semelhança relevante, e nada, no passado dos precedentes, era semelhante ao Holocausto". Para Arendt, o julgamento de Eichmann causou enorme perplexi- 
dade porque evidenciou que o sistema jurídico era não apenas insuficiente, mas completamente inadequado para lidar com o paradoxo de um crime legal.

A partir dessa constatação, aparece em Justiça em tempos sombrios uma reflexão interessante sobre a faculdade de julgar, central a Arendt nos últimos anos de sua vida, quando, após dedicar-se a pensar sobre a condição humana, ela voltou-se para a vida contemplativa, procurando investigar as faculdades fundamentais do espírito. Essa preocupação consubstanciou-se em The Life of the Mind, obra publicada postumamente, que deveria tratar do pensamento, da vontade e do julgamento, mas que não incluiu, como era o plano original de Arendt, esse último tema, uma vez que a morte a surpreendeu quando ela começaria a redigir a terceira parte da trilogia. Essa circunstância faz com que a obra de Christina Ribas enfrente um grande desafio, buscando investigar o tema da justiça, de que Arendt não tratou, a partir da reflexão de Arendt sobre a faculdade de julgar, por ela considerava a mais política das faculdades da mente, mas que ela não chegou a escrever.

Talvez por isso Tercio Sampaio Ferraz Jr., prefaciando a obra, que nasceu de tese de doutorado por ele orientada, na Faculdade de Direito da Universidade de São Paulo, tenha afirmado que a justiça na obra de Arendt é "um não-tema". Buscando apoio em textos anteriores e navegando pelo conjunto da obra de Arendt, Justiça em tempos sombrios nos apresenta a faculdade de julgar de forma oposta à tradição, ancorada na intersubjetividade, a partir do juízo reflexionante estético kantiano, de cujo pensamento Arendt, tão a sua maneira, se apropriou. Nesse sentido, o julgamento é uma faculdade que o pensamento libera, podendo ser desenvolvida, aprendida a partir da experiência e cuja validade, proporcionada pela mentalidade alargada, exige do julgador que assuma a posição de um espectador entre outros, cujas posições tem que considerar; os espectadores só existem no plural, vivendo num mundo de interdependência universal; para Arendt, a pluralidade é a lei da Terra.

Assim percebida, a faculdade do julgamento, para Christina, se traduziria na ponte entre o pensamento e ação, ou, se quisermos, entre a teoria e a prática, constituindo-se numa chave de leitura importante para a obra de Arendt. Daí o livro ocupar-se, em sua terceira parte, do próprio acusado. Como é sabido, Arendt percebeu em Eichmann sua impressionante superficialidade, uma ausência de pensamento, uma irreflexão que a deixou perplexa. Ela, que ao escrever Origens do totalitarismo havia tratado o mal que ali aparecera como radical, apresenta em Eichmann em Jerusalém a tese oposta, a tão célebre e frequentemente mal compreendida tese da banalidade do mal. Deparando-se com Eichmann, Arendt concluiu que apenas o bem pode ser radical, pois o mal não possui qualquer profundidade. Eichmann aparece como um exemplo da incapacidade de pensar que se espalha, de forma avassaladora, no mundo contemporâneo. Entre o pensar e o agir, diz Christina, há um abismo, cuja transposição é complicada justamente porque o mal não é radical, de tal modo que "no fenômeno totalitário, quando os seres humanos se tornaram supérfluos, a sombra projetada por alguns [...] ameaçou atingir toda a terra".

Se a justiça é, como quer Hannah Arendt, e Christina Ribas ressalta, "a matter of judgment", a importância da faculdade de julgar, tanto para a vida a vida contemplativa quanto para a vida ativa, torna-se imensa nas situações-limite, como aquelas que fizeram sua aparição nos períodos totalitários do século $X X$, mas que, a bem da verdade, se constituem em ameaças sempre presentes. Quando a Constitutio libertatis talvez nos falte, com o que poderemos contar? A obra procura compreender esse drama de nossos tempos, nas dobras de cujas sombras nos espiam imensas incertezas. 


\section{$\underline{\text { Sobre o autor }}$}

Odílio Alves Aguiar

Doutor em Filosofia pela USP, professor titular de Filosofia da Universidade Federal do Ceará-UFC.

Recebido em: 5/5/2019

Aprovado em: $2 / 2 / 2020$ 